Whatever happens, the interests of the poorer nations will only be protected where they have the technical basis on which to make informed judgements about transgenic crops, and where a substantial, publicly supported research effort is in place to keep abreast of this increasingly private field of research.

"The more information the developing countries have, the better placed they will be to participate in the debate on biotechnology," Juma told the meeting at the World Bank, adding that this sentiment was not universally accepted.

"We can't deny anybody access to this technology, provided they have full information," says McCalla, warning that the developing countries "must not be foreclosed by others" from deciding how to use transgenics.

But for implementation, resources are needed, even as support for publicly funded agricultural research stagnates around the world. The CGIAR network, for example, has enjoyed what one researcher calls "mission creep without funding creep" in recent years, with new missions such as biodiversity conservation making heavy demands on its $\$ 350$ million annual budget. Less than 10 per cent of its funds are available for biotechnology research.

"We should all be advocates of as strong a public agricultural research system as we can have," declares Sam Dryden, head of the Colorado-based company Emergent Genetics and chair of the CGIAR privatesector committee. "Sam Dryden and I agree on one thing," says Altieri, the biotechnology sceptic who leads the corresponding committee for non-governmental organizations. "Poor farmers' needs are going to be of no interest to the people who control this technology."

Colin Macilwain

\title{
Academies link to map scientific priorities for meeting real needs
}

$\mathrm{R}$ epresentatives from seven scientific academies - two from the developed world and five from the developing world - are planning to meet early next year to agree on guidelines for the type of biotechnology that is most appropriate to developing countries.

The meeting will be the second - the first was held in London in July — of a working group set up to work towards a common position on the scientific and technological priorities for biotechnology in developing nations (see Nature 399, 721; 1999).

The latter are represented on the committee by scientists from the national academies of India, China, Mexico and Brazil — precisely the countries that are engaged in public debate about the relative merits and dangers of the use of biotechnology in crop production - as well as the Third World Academy of Sciences. The developed world is represented by Britain's Royal Society, and the National Academy of Sciences in Washington.

"We are gathering material from the countries concerned to flesh out what is thought to be important for food production in each of them," says Brian Heap, foreign secretary of the Royal Society and an endocrine physiologist who was formerly director of the Babraham Institute, Cambridge.

"We hope to draw together the details in a paper that will, for example, specify the type of trait qualities that will be important for crops in the future. We hope to come to some consensus focusing on what may be called 'phase two' alterations in genetically modified crops, in contrast to the phase one modifications already familiar in developed countries, such as herbicide resistance."

One priority that could be endorsed in such a document, he suggests, is the importance of constructs that increase vitamin A production. "I am also particularly keen to see the problem of anaemia addressed, and in that context increasing the iron content of crops must also be a high priority."

Heap says that the working group is not seeking to diminish the importance of cash crops. "But we are also keen to see emphasis given to such quality traits."

Intellectual property issues have already been high on the working group's agenda. Heap says "we may come forward with recommendations", adding that input from the representatives of the less developed countries will be essential.

"So far we have got quite a measure of agreement and understanding," says Heap. He accepts that in some countries there is strong opposition to the introduction of genetically modifed crops, but says that this will be met through the principle of 'subsidiarity' - the idea that individual members will be free to adopt their own local practices.

"Our concern is to make sure that if there is a clear scientific case for the development of these technologies for the less developed countries, and that they will really make a contribution to food security, then we should say that."

\section{Brazilian farmers are fighting back against legal barriers to GM crops.}

country, by about 20 companies and research institutes. More than 160 trials have been approved by the federal government, mainly corn and soya bean, but also including such crops as sugar cane, tobacco and cotton. Among other GM plants being researched in Embrapa's laboratories is a staple Brazilian food, beans.

But the Brazilian Institute for the Defence of Consumers (IDEC), which together with Greenpeace took the court action to stop commercial use of GM crops, is adamant that GM products must be labelled as such, and segregated from traditional crops. "We are fighting to have rules that work, like labelling, which is fundamental to guarantee freedom of choice," says Marilena Lazzarini, IDEC's executive coordinator.
And the state government in Rio Grande do Sul has banned GM crops completely. Olivio Dutra, the state governor, is from the left-wing Workers' Party, which is at odds with the federal government in Brasilia on most issues. Besides its traditional suspicion of multinational corporations, the party has justified its opposition to GM soya beans on the economic basis that the country's farmers will be able to export GM-free crops to the European Union.

The state has imported kits for testing GM seeds, and the police have burned any that are detected. Some mayors within the state have declared that GM crops are welcome within their municipalities, but they lack any real power to challenge the state government decision.

Farmers' groups are starting to fight back to win access to GM seeds. Four agricultural associations, including the powerful Sociedade Ruralista Brasileira, which represents large commodity farmers, and the association of seed producers, have published full-page advertisements in major newspapers defending "the importance of biotechnology to Brazil". The advertisements argue that GM crops have been proven safe in other countries, and that Brazil has introduced a solid legal framework to regulate genetic engineering.

The farmers argue that further delays in the commercialization of GM crops will harm the country vis-à-vis other major grain exporters where such crops are already being extensively harvested - the United States, Canada, Australia, Argentina, Mexico and China. Ricardo Bonalume Neto 